The Chittagong Univ. J. B. Sci., Vol. 5(1 \&2):01-07, 2010.

\title{
EFFICACY OF ESSENTIAL OILS AS JUTE SEED PROTECTANT
}

\author{
JARIPA BEGUM, M.N. ANWAR ${ }^{1}$, N. AKHTER, MD. NAZRUL ISLAM BHUIYAN** \\ AND M. N. HOQUE \\ BCSIR Laboratories, Chittagong; Chittagong Cantonment, Chittagong-4220, Bangladesh. \\ ${ }^{1}$ Department of Microbiology, Chittagong University, Chittagong-4331, Bangladesh.
}

\begin{abstract}
Essential oils obtained from the leaves of Eucalyptus citriodora, E. camaldulensis, and whole plants of Ocimum gratissimum and O. americanum were tested for their efficiency to protect seed of jute (var.D-154) from seedborne fungal pathogens. A total of 9 fungi were detected. Among the 9 deteced seed borne pathogenic fungi, the highest percentage of fungal occurrence was recorded with Macrophomina phaseolina (37.71\%). This was followed by Botryodiplodia theobromae (30.10\%) and Colletotrichum corchori $(19.72 \%)$. The jute seeds dressed with the oil of Eucalyptus citriodora and Ocimum gratissimum exibited complete elimination of seed fungi, increased seed germination and reduced seedling mortality as compared to that of E. camaldulensis and O. americanum.
\end{abstract}

Key words: Jute, essential oils, seed protectant, antifungal.

\section{INTRODUCTION}

Disease free seeds play a vital role in crop production. But it is known to us that storage fungi degrade the nutritional components of seeds and also produce mycotoxins which cause reduced seed germination and increase seedling mortality while and more house 1977, 1978. Due to the growing concern about the toxicity of seed dressing organo-mercurials and development of resistance in the pathogens against such fungicides, search for various naturally occurring compounds with antifungal activity has become quite intense. It is advocated that these seed protecting fungicides should ideally be safe and non polluting (Fawcet and Spencer 1970, Khosoo 1986). Many essential oils have been found to possess varied degree of toxicity against different fungal pathogens (Rao and Nigam 1978, Thind and Suri 1979, Sinha and Gulati 1990, Begum et al. 1997, 1999, 2007, Chowdhury et al. 2003). Jute suffers from more than 12 different diseases. Of them, 10 are known to be seed borne (Hoque et al. 2005). Control of seedborne fungi by various plant extracts were well documented ( Ahmed and Sultana 1984, Khan and Fakir 1995). The present study was undertaken to evalute the

* Corresponding author:nazrul119@yahoo.com

$-2$ 
seed protectant efficacy of essential oils collected from Eucalyptus citriodora Hook, E. camaldulensis Dehnh, Ocimum gratissimum L. and O. americanum L.. It should be ponted out that these plants are the important source of essential oils which are extensively used in perfumery and medicine (Guenther 1972, Yusuf et al.1994).

\section{MATERIALS AND METHODS}

Extraction of essential oils

Essential oils were extracted from fresh leaves of E. camaldulensis, E. citriodora and whole plants of Ocimum gratissimum and $O$. americanum by hydrodistillation through Clevenger's apparatus. E. camaldulensis and E. citriodora were collected from Chittagong University Campus, Bangladesh and $O$. gratissimum and $O$. americanum were collected from BCSIR Laboratories, Chittagong and Chittagong plantation area, Bangladesh. The essential oils thus collected were dried over anhydrous sodium sulfate and stored in sterile bottles for experimentation. Four voucher specimens of the plant have been preserved in the Herbarium of BCSIR Laboratories, Chittagong, Bangladesh.

\section{Collection of seed sample}

Jute seeds(var. D-154) were collected from Bangladesh Jute Research Institute, Dhaka. Seeds were brought to the laboratory, kept in paper bags and stored in desiccators until they were used for investigation.

\section{Detection of mycoflora and testing of seed health}

Jute seeds were analyzed for the detection of seed associated fungi, $\%$ germination and seedling mortality were determined by blotter method as recommended by International Seed Testing Association (ISTA 1966). Fungi were identified by steriobinocular microscopic observation (Agarwall et al. 1972). Individual fungus was isolated and purified by repeated streak method on PDA.

\section{Seed treatment with oils}

Seeds of jute (var. D-154) were taken in a sterile container. For each treatment 400 seeds were taken. The seeds were treated with 1\%, 2\% and 3\% (W/V) oil separately. The container was closed tightly and shaken well to mix the seeds with oil. A control set without oil was also maintained for each treatment. The prevalence of associated fungi, seed germination and seedling mortality of treated and control seeds were examined after 30,60 and 90 days of storing at room temperature $\left(27 \pm 2^{0} \mathrm{C}\right)$. 


\section{ESSENTIAL OILS AS JUTE SEED PROTECTANTS}

\section{RESULTS AND DISCUSSION}

The total number of fungi associated and their occurrence (jute seeds var. D-154), per cent germination and seedling mortality are shown in Table-1. A total of 9 fungi including eight fungal genera (Macrophomina phaseolina, Botryodiplodia theobromae, Colletotrichum corchori, Chaetomium sp., Rhizopus sp., Aspergillus sp., Penicillum sp., Fusarium sp.) and Mycelia sterilia were detected during investigation (Table.1). The highest percentage of fungal occurrence were recorded with Macrophomina phaseolina (37.71\%) followed by B. theobromae $(30.10 \%)$ and C. corchori $(19.72 \%)$. Table.1- revealed that among 1800 seeds 289 were infected with fungi, germination percentage was 91.0 and seedling mortality was $11.7 \%$. The efficacy of four essential oils at three different doses and with three different working periods on three major and other minor seed borne fungal pathogens of jute along with the percent seed germination and percent seedling mortality are shown in Table 2 . It was observed that all the fungal pathogens showed susceptibility towards the four essential oils tested. The degree of susceptibility varied depending on the species as well as the dose given. The oil $(1 \%)$ of E. citriodora and $O$. gratissimum were superior in eliminating the seed fungi (except $M$. phaseolina,) reducing seedling mortality and enhancing seed germination compared to that of E. camaldulensis and $O$. americanum. But at $2 \%$ and $3 \%$ dose of these two oils, completely eliminated seed fungi and seedling mortality, also caused increase in seed germination percentage (Table 2). Seed protectant property of essential oils of Zingiber officinale was reported earlier (Mishra 1990). Al-Mousawi and Al-Maib (1976) reported that Eucalyptus oil inhibits germination of seed, but in this study this oil was found to enhance germination of jute seeds. Jute is the major cash crop of Bangladesh. So, protection of seeds from fungi during storage is of utmost importance for growing healthy plants. This finding suggests that the oils of E. citriodora and $O$. gratissimum may be utilized as indigenous seed protectants to control seed borne fungal pathogens of jute seeds. These essential oils have no gross toxicity on white strain rats during oral dose (Sinha and Gulati 1990, Begum et al.1997). Besides, these oils appear to be non toxic to human beings because they have been already used medicinally(Guenther 1972, Yusuf et al. 1994).

Variations in reductions of seedling mortality due to various treatments (types of oils, doses of oils, and treatment interactions) of this study were found to be significant at $1 \%$ and $5 \%$ levels as per ANOVA. 
BEGUM ET AL.

TABLE 1: OCCURRENCE OF SEED BORNE FUNGI, PERCENT SEED GERMINATION AND MORTALITY OF SEEDLING OF JUTE (VAR.D-154).

\begin{tabular}{|c|c|c|c|c|c|}
\hline Fungal species & $\begin{array}{c}\text { Total } \\
\text { number of } \\
\text { fungi }\end{array}$ & $\%$ fungi & $\begin{array}{l}\% \text { infected } \\
\text { seeds }\end{array}$ & $\begin{array}{c}\% \text { seed } \\
\text { germination }\end{array}$ & $\begin{array}{c}\% \\
\text { seedlings } \\
\text { mortality }\end{array}$ \\
\hline $\begin{array}{c}\text { Macrophomina } \\
\text { phaseolina }\end{array}$ & 109 & 37.71 & 6.05 & & \\
\hline $\begin{array}{c}\text { Botryodiplodia } \\
\text { theobromae }\end{array}$ & 87 & 30.10 & 4.83 & & \\
\hline $\begin{array}{l}\text { Colletotricum } \\
\text { corchori }\end{array}$ & 57 & 19.72 & 3.16 & & \\
\hline Chaetomium sp. & 10 & 3.46 & 0.55 & & \\
\hline Rhizopus sp & 7 & 2.42 & 0.38 & 90.80 & 11.70 \\
\hline Aspergillus sp. & 10 & 3.46 & 0.55 & & \\
\hline Penicillium sp & 5 & 1.72 & 0.27 & & \\
\hline Fusarium sp. & 3 & 1.03 & 0.16 & & \\
\hline Mycelia sterilia & 1 & 0.34 & 0.05 & & \\
\hline Total & 289 & 99.96 & 16.00 & & \\
\hline
\end{tabular}

* Percent of fungi was calculated on the basis of total number of fungi associated with seeds i.e. 289.

* Percent of seed germination was calculated on the basis of total no. of seeds i. e. 1800 seeds 


\section{ESSENTIAL OILS AS JUTE SEED PROTECTANTS}

\section{TABLE 2: EFFICACY OF ESSENTIAL OILS TO PROTECT JUTE SEEDS FROM MAJOR}

AND OTHER SEED- BORNE FUNGAL PATHOGENS.

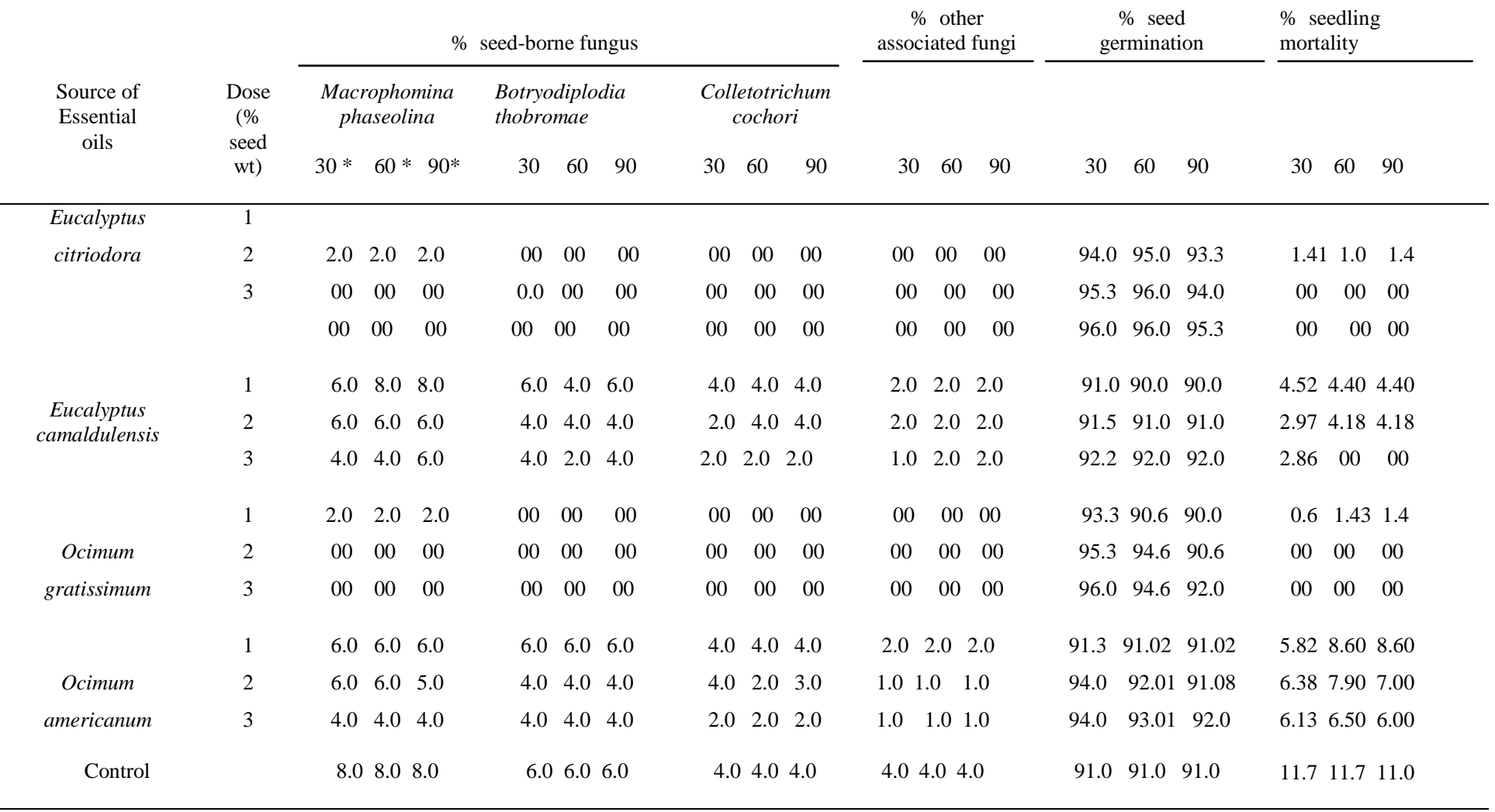


BEGUM ET AL.

\section{REFERENCES}

AGARWALL, V.K. MATHUR, S. E. AND NEERGARD, P. 1972. Some seed health testing with respect to seed borne fungi of rice, wheat, black gram, green gram and soybean grown in India. Indian phytopath. 25: $91-100$.

AHMED, N. AND SULTANA, K. 1984. Fungitoxic effect of garlic on treatment of jute seed. Bangladesh J. Bot.13 (2):130-136.

AL-MOUSAWI, A.H. AND AL-MAIB, F.A.G. 1976. Volatile growth inhibition produced by Eucalyptus microtica. Bulletin of the Biological Research Center. 1: 17-23.

BEGUM, J., CHOWDHURY, J. U., YUSUF., M, WAHAB, M. A., AHMED, K., AKHTER, N. AND ANWAR, M. N. 1997. Evolution of oils extracted from Eucalyptus citriodora and E. camaldulensis for antimicrobial properties and their toxicity in rats. Bangladesh J. Sci., Ind. Res., 32 (4): 561-566.

BEGUM, J. , CHOWDHURY, J. U. YUSUF, M., WAHAB, M. A., AHMED, K. AKHTER, N. AND ANWAR, M. N. 1999. Antimicrobial activity of essential oils isolated from the Ocimum amricanum and O. gratissimum var. clocimum and their toxicity in white strain rats. Bangladesh J. Microbiol., 16 (2): 127-134.

BEGUM, J., DUTTA, S., YUSUF, M., CHOWDHURY, J.U., K. AHMED, J.U. , AHMED, S. AND ANWAR, M.N. 2007. Antimicrobial activity of Cinamomum tamala essential oil and its composition and toxicity on white strain rats. Bangladesh J. Microbial., 24 (1): 14-18.

CHOWDHURY, J. U., BEGUM, J., YUSUF, M., SULTANA, S.A. AND HUSAIN, M.M.. 2003. Composition and fungi toxic properties of the essential oil of Lippia javanica leaves. Indian Perfumer 47(4): 385-388.

FAWCET, C. H. AND SPENCER, D. M. 1970. Plant chemotherapy with natural products. Ann. Rev. Phytopathol. 8: 403-418.

GUENTHER E. 1972. The essential oils vol. IV, Robert E. Krieger publishing Co., INC, Huntington, New York, Pp. 448,504-25.

HOQUE, M. Z., BEGUM, N., PATWARY, M. M. A. AND FAKIR, G.A. 2005. Effect of location on seed health status of four categories of jute seeds in Bangladesh. Bangladesh J.Plant Path. 21(1-2):24-28.

ISTA 1966. International rules of seed testing association. Proc. Int. Seed Testing Assoc. 31: 1-152.

KHAN, A.A AND FAKIR, G.A.1995.Seed treatment with garlic extract tocontrol seed-borne pathogens of jute. Bangladesh J. Plant Path.11(1-2):1-2. 
ESSENTIAL OILS AS JUTE SEED PROTECTANTS

KHOSOO, T.N 1986. Environmental Priorites in India and sustainable development .Presidential address, $73^{\text {rd }}$ session India congress, New Delhi.

MISHRA, M. 1990. Seed protectant property of essential oil of Zingiber officinale Roscoe. Indian Perfumer, 34 (4): 266-268.

RAO, R.S.S. AND NIGAM, S.S. 1978. Chemical and antimicrobial examination of the essential oil from seeds of Nigella sativa var. aromatica. Indian Perfumer, 22 (4): 232-238.

SINHA, G.K. AND GULATI ,B.C..1990. Antibacterial and antifungal study of some essential oils and some of their constituents. Indian perfumer, 34 (2): 126-129.

THIND, T.S. AND SURI, R.K.1979. Invitro antifungal efficacy of four essential oils. Indian perfumer, 23 (2): 138-140.

WYLLIE, T.D. AND MOREHOUSE, L.G. 1977. Mycotoxic fungi, Mycotoxins, Mycotoxicoses Vol. II. Marcel DekkerInc. New York.pp.91-98.

WYLLIE, T.D. AND MOREHOUSE, L.G. 1978. Mycotoxic fungi, Mycotoxins, Mycotoxicoses Vol. II. Marcel Dekker Inc. New York. pp. 91-108.

YUSUF, M, CHOWDHURY, J.U. WAHAB M. A. AND BEGUM. J. 1994. Medicinal Plants of Bangladesh, BCSIR), Dhaka. pp. 179-180.

Manuscript received on 3. 12. 2009; Accepted on 29.9.11

The Chittagong University Journal of Biological Sciences, Vol. 5 (1 \& 2). Page No:01-07 